\title{
APPROACHES TO DEVELOPING FUTURE TEACHER LEADERSHIP TO ENHANCE STUDENTS' HUMAN VALUE CREATING GLOBAL CITIZENSHIP
}

\author{
Nantarat Charoenkul ${ }^{1^{*}}$ \\ ${ }^{1}$ Educational Administration, Faculty of Education, Chulalongkorn University, Thailand \\ 1 adiitya_sehgal@scmhrd.edu
}

\begin{abstract}
This research aims to: 1) study the present and desirable states and priority needs of future teacher leadership development; 2) propose approaches to developing future teacher leadership to enhance students' characteristics based on the human value creating global citizenship concept. This study used a mixed-method approach. The sample population comprised 220 volunteer student teachers, 68 school administrators and teacher mentors, plus 16 experts, totally 304. The research instruments were questionnaires and interviews, plus an evaluation form. Data were analysed by frequency, percentage, mean, standard deviation, Modified Priority Needs Index ( $\left.\mathrm{PNI}_{\text {Modified }}\right)$ and content analysis. The research findings reveal that there are 4 future teacher development main approaches: 1. Develop student teachers' personal growth to be the role models coaching students to conduct knowledge and wisdom-based lives and to respect human value in themselves and others; 2. Exalt student teachers' leadership competency to be the role models having a service mind, equipping students with team working skills and social justice-based interaction capacity; 3. Cultivate a model teacher's spirituality in student teachers to support students to conduct their lives based on sufficiency and sustainability; 4. Enhance student teachers' potential to become the model researchers endowing students with dialectic critical thinking through proactively practical guidelines.
\end{abstract}

Keywords

Future teacher leadership development; Students' characteristics based on the human value creating global citizenship concept; Student teachers.

Article Received: 10 August 2020, Revised: 25 October 2020, Accepted: 18 November 2020

\section{Introduction}

Human-oriented education and promotion of understanding amongst educational administrators, teachers, students and all the parties concerned about human value in themselves while respecting human rights and dignity of others have become a critical issue worldwide. As the human value creating theories and concepts have significantly contributed to fostering a global citizen and cultivating beliefs in peace and tranquility in the society, many studies have been conducted on such theories and concepts in both western and eastern regions, especially the latter. In eastern countries, where people-oriented development has become high on agenda of national and international academic forums. Furthermore, it was highlighted in an Education for Sustainable Development conference organized by UNESCO at University of London Research Institute, England, in May 2018 (cited in Sharma, 2018) where many academics and researchers reflected on value creating education and practical guidelines for investigations on global citizenship emphasizing any paradigms and perspectives to be applied as the approaches for learning to live together. This was an intriguing concept which led to the formulation of key issues and queries for national development research under the main topic of education for global citizenship (UNESCO, 2014). Also, it was referred and stated in national plans and policies in various countries, including Thailand where human resource development has been focused and cited in its national plans, such as the present national economic and social development plan (from 2017-2021), Thailand national education standards 2018 and national education plan (from 2017-2036). Moreover, educational development plans and strategies at many levels have addressed the significance and need of developing human resources along with promoting a learning and peaceful society that will pave the way for attaining the country's vision of stability, prosperity and sustainability. In the new era of 4.0, it requires development of human resources and enhancement of the characteristics of both quality teachers and students, to be equipped with ethical values and to 
keep pace with any global changes. Besides academic and ICT capacities, it is necessary that the philosophy of value creating education and the related beliefs are translated into action, being integrated into any educational institution or school curriculum, programs and activities. Due to the main objective of the Human World study with an emphasis on developing the new generation people's potential and capability, any parties and organizations in charge of educating and growing young people have to apply the value creating education principles through their instructional activities and pedagogies aiming to cultivate humanity in an individual. Such principles focus on the role of education in building respect for human dignity, growing a person who is reliable and creates value through dialectic critical thinking, with a service mind and concerns for social justice, and who leads a life based on both knowledge and wisdom, while holding sufficiency and sustainability (Ikeda, D., 2009). This will lead to success in life and a peaceful society. Hence, apart from the $21^{\text {st }}$ century skills: learning and creating innovations, ICT competency as well as life and career skills, school administrators, teachers and all the parties concerned should apply the human value creating education principles and concepts as well as the global citizenship philosophy, translating them into practice so that young and new generation learners are endowed with human value sustaining their respect for themselves and others, a service mind and capability of living a life based on both knowledge and wisdom, which are the main complementary elements of the human value creating philosophy towards development of a global citizen (Charoenkul, N. et al., 2019).

To develop students as human resources holding the future of the nation and the world, teachers have considerable influence on and take an important role in creating and enhancing students' desirable characteristics to respond to the need of the society and to tackle with any problems effectively. For driving human resource development and manpower in the 4.0 era, it requires power and leadership skills of the new generation teachers and those who tend to be future teachers, who will efficiently impart to students the essential knowledge, skills and desirable characteristics for being the human value creating global citizens who will meaningfully pass on their virtues to create the great value for the society and the world. Accordingly, future teachers need to continuously develop themselves to be the model teachers who coach and advise their students while collaborating with and advocating them from time to time (Fairman, J.C. \& Mackenzie, S.V., 2015). Furthermore, they also need to be well equipped with teacher leadership qualities and skills in all dimensions: growth as a teacher; growth as a researcher; growth as a leader and personal growth, while being concerned about context, impact, and challenges (Poekert, P.E. et al., 2016). To effectively drive the national education development plan, it is necessary to promote strength and to develop graduates, especially in the field of education, to be endowed with the indispensable qualifications of the quality and valuable citizens of the nation and the world. In this regard, it is essential to carry out a study on the approaches to developing future teacher leaders who will play a significant role in enhancing students' characteristics based on the human value creating global citizenship concept.

This research aims to: 1) study the present and desirable states and priority needs of future teacher leadership development enhancing students' characteristics; 2) to propose approaches to developing future teacher leadership enhancing students' characteristics based on the human value creating global citizenship concept.

\section{Research Methodology}

This research applied a mixed method approach consisting of both quantitative and qualitative designs, with the main 2 phases as follows.

Phase 1. involved a quantitative study on the current and desirable states as well

as priority needs of developing future teacher leadership enhancing students' characteristics based on the human value creating global citizenship concept. Population and sample population comprised 68 middle-level school administrators or heads of the subjects/heads of the divisions and teacher mentors/supervisors -academic staff in charge of student teacher supervision--, as well as 220 volunteer student teachers in the course of their apprenticeship at schools or educational institutions nationwide. This study followed a universal criterion on the sample size of population, with error allowed at +/- 5 \% (Krejcie, R.V. \& Morgan, D.W.,1970). 
The research instrument was divided into 3 sets of 5-point rating-scaled questionnaires for school administrators, teacher mentors/supervisors and student teachers. The questionnaires cover the current and the desirable states of instructional management and development of students' characteristics based on the human value creating global citizenship concept and the desirable state of teacher leadership and future teacher leadership development. They were verified in terms of content validity by 5 experts in educational management, leadership and global citizenship, with the Index of Congruence (IOC) of 0.80-1.00 or over 0.50 as a standard criterion for selecting the appropriate and valid items (Kanchanavasee, S., 2009). Data were analyzed by frequency, percentage, mean and standard deviation (S.D.). The mean values were analyzed and classified into 5 levels: $4.50-5.00$ stands for the current/desirable state at the highest level; 3.50-4.49 means the high level; 2.50-3.49 stands for the moderate level; 1.50-2.49 means the low level, and 1.00-1.49 stands for the lowest level. For Modified Priority Needs Index (PNI Modified), the formula PNIModified $=(\mathrm{I}-\mathrm{D}) / \mathrm{D}$ was applied, having "I" for the desirable state of student teachers' instruction and of developing students' characteristics based on the human value creating global citizenship concept, and " $\mathrm{D}$ " for the current state of student teachers' instruction and of developing students' characteristics based on the human value creating global citizenship concept. The data derived from phase 1 were primarily used for drafting the approaches to developing future teacher leadership enhancing students' characteristics based on the human value creating global citizenship concept.

Phase 2. was related to a proposal of the approaches to developing future teacher leadership enhancing students' characteristics based on the human value creating global citizenship concept. A qualitative approach was applied for collecting the key data concerning the Research Results ideas and suggestions from 3 groups of respondents, concerning development of future teacher leaders to enhance students' desirable characteristics based on the human value creating global citizenship concept. This phase was divided into 2 parts: interviewing with the selected 30 middle-level school administrators (heads of subject/of division) and teacher mentors /supervisors with knowledge and experience in coaching and supervising student teachers, plus 30 representatives of volunteer student teachers from each major field who had actively participated and provided some intriguing ideas in phase 1 , and having 16 academics, with expertise in value creating education, global citizenship, development of human resources in education, student teacher mentoring and supervision, verify appropriateness and feasibility of the approaches to developing future teacher leadership enhancing students' characteristics based on the human value creating global citizenship concept. The research instruments included semi-structured interviews to collect in-depth data from administrators, teacher mentors /supervisors and student teacher representatives about instructional and learning management activities to enhance students' characteristics based on the human value creating global citizenship concept, and approaches to developing future teacher leadership. A 5-point rating-scaled evaluation form, including openended questions, for appropriateness and feasibility of the drafted approaches to developing future teacher leadership was distributed to the cooperative experts. Data were analyzed by frequency, percentage and content analysis, choosing some interesting ideas relating to future teacher leadership of student teachers who were supposed to take a critical role in improving students' soft skills and global citizenship characteristics. Whereas data derived from the experts who verified the drafted approaches were analyzed using mean, standard deviation and content analysis.

\begin{tabular}{|c|c|c|c|c|}
\hline \multirow{3}{*}{ Items } & \multicolumn{4}{|c|}{ All groups of respondents } \\
\hline & Current (D) & Desirable (I) & PNIModif & Rank \\
\hline & S.D. & S.D. & (1) & \\
\hline
\end{tabular}




\begin{tabular}{|c|c|c|c|c|c|c|c|}
\hline & \multirow{3}{*}{ Items } & \multicolumn{6}{|c|}{ All groups of respondents } \\
\hline & & \multicolumn{2}{|c|}{ Current (D) } & \multicolumn{2}{|c|}{ Desirable (I) } & \multirow{2}{*}{$\begin{array}{l}\text { PNIModif } \\
\text { ied }\end{array}$} & \multirow[t]{2}{*}{ Rank } \\
\hline & & $\overline{\mathbf{x}}$ & S.D. & $\overline{\mathbf{x}}$ & S.D. & & \\
\hline 1 & $\begin{array}{l}\text { 1.Respect human } \\
\text { value in oneself and } \\
\text { others }\end{array}$ & 3.74 & 0.85 & 4.62 & 0.64 & 0.235 & 2 \\
\hline 2 & $\begin{array}{l}\text { 2.Hold sufficiency } \\
\text { and sustainability }\end{array}$ & 3.75 & 0.82 & 4.59 & 0.65 & 0.224 & 4 \\
\hline 3 & $\begin{array}{l}\text { 3.Root the service } \\
\text { mind, team } \\
\text { working } \\
\text { skills and social } \\
\text { justice-based }\end{array}$ & $\mathbf{3 . 8 3}$ & 0.85 & 4.66 & 0.63 & 0.217 & 5 \\
\hline 4 & $\begin{array}{l}\text { interaction } \\
\text { 4.Encourage } \\
\text { proactively } \\
\text { practical guidelines } \\
\text { for enhancing }\end{array}$ & 3.78 & 0.85 & 4.65 & 0.60 & 0.230 & 3 \\
\hline 5 & $\begin{array}{l}\text { dialectic critical } \\
\text { thinking } \\
\text { 5.Lead a life based } \\
\text { on both knowledge } \\
\text { and wisdom }\end{array}$ & 3.74 & 0.82 & 4.67 & 0.59 & 0.249 & 1 \\
\hline
\end{tabular}

Table1. The overall results of the current and desirable states and $\mathrm{PNI}_{\text {Modified }}$ of future teachers' instruction to enhance students' characteristics based on the human value creating global citizenship concept.

From table 1, it turns out that, overall, the current state of instruction by student teachers or future teachers to enhance students' characteristics based on the human value creating global citizenship concept was at the high level $(\overline{\mathrm{x}}=3.77$, S.D. $=0.84)$, with the highest mean on rooting the

\section{$\begin{array}{lll}4.64 & 0.62 & 0.231\end{array}$}

service mind, team working skills and social justice-based interaction

$(\bar{x}=3.83$, S.D. $=0.85)$. Whereas the desirable state is, overall, at the highest level ( $\bar{x}=4.64$, S.D. 0.62), having the highest mean on leading a life based on both knowledge and wisdom ( $\bar{x}=4.67$, S.D. $=0.59)$. The result of priority need analysis reveals that the aspect with the highest need index is leading a life based on both knowledge and wisdom $\left(\mathrm{PNI}_{\text {Modified }}=0.249\right)$, followed by respecting human value in oneself and others $\left(\mathrm{PNI}_{\text {Modified }}=0.235\right)$.

All groups of respondents

An Overall Picture of the Desirable State of Future Teacher Leadership and Leadership Development

\begin{tabular}{ll}
\hline Desirable State & Rank \\
\hline $\bar{x}$ & S.D
\end{tabular}


All groups of respondents

An Overall Picture of the Desirable State of Future Teacher Leadership and Leadership Development

\begin{tabular}{|c|c|c|}
\hline \multicolumn{2}{|c|}{ Desirable State } & \multirow[t]{2}{*}{ Rank } \\
\hline $\bar{x}$ & S.D & \\
\hline 4.67 & 0.54 & \multirow{4}{*}{$\begin{array}{l}1 \\
3 \\
8 \\
6\end{array}$} \\
\hline 4.63 & 0.61 & \\
\hline 4.56 & 0.61 & \\
\hline 4.60 & 0.59 & \\
\hline & & \multirow{8}{*}{$7^{10}$} \\
\hline 4.61 & 0.57 & \\
\hline 4.54 & 0.60 & \\
\hline 4.62 & 0.59 & \\
\hline 4.66 & 0.56 & \\
\hline 4.56 & 0.64 & \\
\hline 4.50 & 0.68 & \\
\hline 4.59 & 0.61 & \\
\hline 4.59 & 0.60 & \\
\hline
\end{tabular}

Table2. The overall picture of the desirable state of future teachers' leadership and leadership development.

With reference to table 2 , it demonstrates that the desirable state of leadership and developing future teacher leadership, overall, is at the highest level $(\overline{\mathrm{x}}=4.59$, S.D. $=0.60)$, with the highest mean on modeling $(\bar{x}=4.67, \quad$ S.D. $=0.54)$, followed by personal growth $(\overline{\mathrm{x}}=4.66, \quad$ S.D. $=0.56)$ and coaching $(\overline{\mathrm{x}}=4.63$, S.D. $=0.61)$.

According to the interviews and additional suggestions from 60 administrators, teacher mentors/supervisors and student teacher representatives from each major subject who provided some intriguing ideas on the approaches to developing future teacher leadership enhancing students' characteristics based on the human value creating global citizenship concept, new generation teachers should be earnestly coached and should develop themselves to be leaders, while being the role models for their students, especially in work process managing, team working skills, teaching and learning capacities and other skills that help enhance the soft skills, such as being responsible, punctual and courteous, being equipped with professional ethics and teacher spirituality, having a service mind, and being capable of differentiating between fairness versus partiality and courage versus vulgarity, etc.
Apart from this, future teachers should continuously improve themselves in managing a teaching plan and creating innovative teaching instruments using ICT and various kinds of applications and social media. Furthermore, they should actively collaborate with teacher mentors and school staffs as well as student teachers from other institutions in arranging any social interaction activities to promote students' concerns about diversity and cross-cultural understanding, adaptability to any situations by refusing and avoiding violence, creating an atmosphere conducive to collaborating and living happily with others, while holding sufficiency and sustainability. Moreover, the administrators and teacher mentors emphasized the significance of the principles of sufficiency and sustainability that could be imparted to student teachers or future teachers and further transferred to students through instructional and active learning activities, by integrating teaching and classroom research in conformity with such principles. However, school administrators, teacher mentors/supervisors could facilitate student teachers to fully improve themselves and their teaching focusing on the ultimate goal of student development.

The research findings reveal that there are 4 main approaches to developing future teacher leadership as shown in Figure1. 


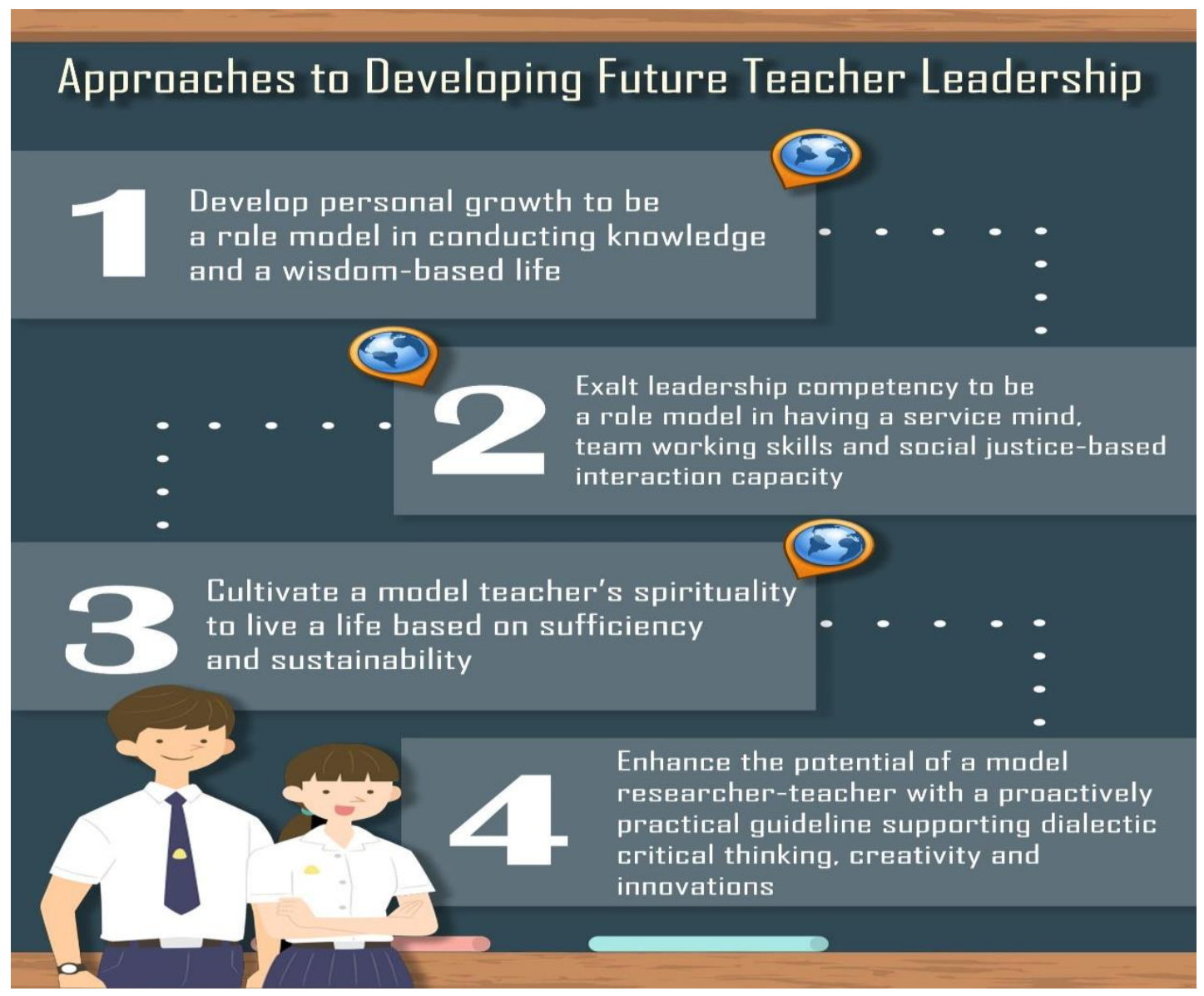

Figure 1.. Approaches to Developing Future Teacher Leadership to Enhance Students' Human Value Creating Global Citizenship

Figure 1 presents 4 main approaches to developing future teacher leadership which is expected to help enhance students' characteristics of people-oriented global citizens who meaningfully create value for the society and the world. These approaches cover 8 procedures and 5 goals, of which the details are as follows.

Approach 1 Develop student teachers' personal growth to be the role models

guiding, coaching and supporting students to conduct knowledge and wisdom-based lives and to respect human value in themselves and others for living together happily and harmoniously, with 2 procedures and 2 goals.

\section{Procedures:}

1) supervisors of the student teachers, teacher mentors and the student teachers themselves collaborate in planning, defining and supporting personal growth of student teachers by advising them to learn from some model teachers and academics, to conduct lives based on both knowledge and wisdom, to respect values in themselves and others for living together in happiness and harmony, to be flexible and adaptable to any situations, to be capable of teaching and communicating across cultures, to keep pace with new technologies and media, as well as to have team working skills.

2) Student teachers enhance their own personal growth, developing themselves continuously to be a role model for their students, to coach, train and support students to live their lives based on knowledge and wisdom and to respect values in themselves and others for living together in happiness and harmony. In addition, student teachers collaborate with their supervisors and teacher mentors in monitoring, concluding and carrying out the lessons learned for selfdevelopment.

Goals:

1) Students can conduct their lives based on knowledge and wisdom, effectively

cope with their emotions and stress, and be adaptable to any situations. 
2) Students respect human value in themselves and others, and have positive

interactions with peers/seniors and juniors.

Approach 2 Exalt student teachers' leadership competency to be the role models

concerning having a service mind, guiding, coaching and equipping students with team

working skills and social justice-based interaction capacity, with 2 procedures and a goal.

Procedures:

1) Teacher mentors and supervisors of student teachers provide guidance and suggestions, and monitor to assure that student teachers can improve their leadership competency, especially in having a service mind, through some case studies, knowledge exchanges and lessons learned activities that help elevate themselves to be the model leaders. Furthermore, student teachers can apply what they have learned as guidelines for teaching and transferring the positive characteristics, such as being able to cope with emotions and stress, having a service mind and team working skills, to their students.

2) Student teachers upgrade their leadership competency to be the model teacher leaders through case studies, trainings and seminars, field trips, so that they can coach, train and support their students to be endowed with team working and social justice-based interaction skills. Furthermore, student teachers collaborate with their supervisors and teacher mentors in selfreflections and exchanges of some valuable ideas.

Goal:

Students have a service mind as well as team working and social justice-based interaction skills. Approach 3 Cultivate a model teacher's spirituality in student teachers to guide, coach and support students to conduct their lives based on sufficiency and sustainability, with 2 procedures and a goal.

Procedures:

1) Supervisors, teacher mentors and student teachers collaborate in constructing and defining the simulations or role plays which help develop student teachers to be the model teachers holding sufficiency and sustainability, getting supported by peers and their teacher mentors/supervisors to be leaders in any activities and work. Having learned from the simulations/role plays, student teachers can apply these for supporting their students in conducting lives based on sufficiency and sustainability.

2) Supervisors, teacher mentors and student teachers themselves collaborate in advising, monitoring and improving student teachers to be the role models in holding sufficiency and sustainability and to further advise, coach and support their students in conducting lives based on sufficiency and sustainability.

Goal:

Students understand and hold sufficiency and sustainability.

Approach 4 Enhance student teachers' potential to become the model researchers guiding, coaching and endowing students with dialectic critical thinking through proactively practical guidelines, with 2 procedures and a goal.

\section{Procedures:}

1) Supervisors, teacher mentors and student teachers collaborate in planning and developing student teachers' potential of being the model researcher-teachers through conducting classroom research, enabling student teachers to coach and support students in living with dialectic critical thinking and creativity through proactively practical guidelines for creating innovations.

2) Supervisors, teacher mentors and student teachers themselves collaborate in advising and monitoring development of students teachers' potential and enhancement of their knowledge and practical experiences so that they become the model researcher-teachers, promoting student teachers to participate in professional trainings/workshops to develop their potential of research conducting while coaching them to be efficient facilitators and supporters guiding their students to conduct lives with dialectic critical thinking and creativity through proactively practical guidelines for creating and developing innovators.

Goal:

Students can wisely apply some proactively practical guidelines to enhance their dialectic critical thinking and creativity.

The results of appropriateness and feasibility evaluation of the drafted approaches to developing future teacher leadership enhancing students' characteristics based on the human value creating global citizenship concept by 16 experts reveal that, overall, the appropriateness is at the highest 
level $(\overline{\mathrm{x}}=4.66, \mathrm{SD}=0.55)$, while the feasibility appears at the high level $(\overline{\mathrm{x}}=4.30, \mathrm{SD}=0.96)$.

\section{Discussion and Conclusion}

From the proposed approaches to developing future teacher leadership

to enhance students' characteristics based on the human value creating global citizenship concept, there are some intriguing issues to be discussed as follows.

Approach 1 Develop student teachers' personal growth to be the role models

guiding, coaching and supporting students to conduct knowledge and wisdom-based lives and to respect human value in themselves and others for living together happily and harmoniously meaningfully signifies the important role of global citizens who create human value in themselves, conducting lives based on both knowledge and wisdom, which appears the aspect with the highest PNIModified. While considering the desirable state of teacher leadership development, personal growth becomes a critical aspect with the highest mean. This meaningfully reflects the significance of developing some approaches to enhancing global citizenship in new generation people and students who should be equipped with curiosity and inquisitive mind leading them to discover themselves as the individuals with some beliefs, experience and unlimited capacities. Eventually, students will have holistic understanding about themselves, others and the world (Pike, G. \& Selby, D., 2000) through self-reflection. This will help motivate students as the individuals willing to take part in any societal changes, while creating engagement and emphasizing awareness of and determination to create a value in themselves (Bourn, D. \& Sharma, N., 2008).

Approach 2 Exalt student teachers' leadership competency to be the role models concerning having a service mind, guiding, coaching and equipping students with team working skills and social justice-based interaction capacity reflects modelling, an important aspect of the desirable state of teacher leadership with the highest mean. A model teacher is expected to open their minds to any innovative ideas and/or criticisms. In terms of coaching, he/she should be equipped with a variety of pedagogical skills to motivate students' learning through social media, using interdisciplinary approaches or integrating bodies of knowledge between sciences. This conforms to the theory of a leadership behaviour development framework (Srisa-arn, V., 2020) and a concept of the team working skills focusing on knowledge exchange and knowledge transfer, while having faith in the potential and capacity of oneself (Andrea, B. et al., 2016). Also, it emphasizes the necessity of developing soft skills in parallel with ICT competency and other practical skills (Filipczak, B. et al., 2000). Hence, it is essential to cultivate in student teachers/future teachers some leadership skills and characteristics while working and learning with their students (Salazar, Y.C., 2010).

Approach 3 Cultivate a model teacher's spirituality in student teachers to guide, coach and support students to conduct their lives based on sufficiency and sustainability meaningfully signifies what was emphasized by school administrators and teacher mentors/supervisors who rated holding sufficiency and sustainability as an aspect with the highest level, in terms of the overall desirable state of future teachers' instruction to enhance students' characteristics based on the human value creating global citizenship concept. This also corroborates the result of appropriateness and feasibility of the proposed approaches evaluated by 16 experts. Moreover, this supports some ideas on developing future teacher leadership (Poekert, P.E. et al., 2016), future teacher leadership (Fairman, J.C. \& Mackenzie, S.V., $2012 \&$ 2015), the human value creating global citizenship concept (Charoenkul, N. et al., 2019), and the theory of a leadership behaviour development framework focusing on the dimension of value and ideology highlighting the common good, having a service mind, as well as holding ethical and moral principles, etc. (Srisa-arn, V., 2020).

Approach 4 Enhance student teachers' potential to become the model researchers guiding, coaching and endowing students with dialectic critical thinking through proactively practical guidelines significantly reflects the necessity that student teachers/future teachers guide and help enhance students' innovation discovery and creating skills, and that they advise students to make a decision and solve any problems and conflicts in a peaceful and creative way. These appear the items of the highest PNIModified in terms of encouraging proactively practical guidelines for enhancing dialectic critical thinking, which falls in the top 3 main aspects 
with the highest PNIModified. This conforms to the characteristics of new generation teachers who need to become the innovators creating innovations (Mesinsee, S., 2019) and the principles of educational management in the digital age, having ethics to lead knowledge (Sophonpanich, K.., 2020), as well as developing professional or model researchers which is consistent with the theory of a leadership behaviour development framework (Srisa-arn, V., 2020). All of the mentioned theories and concepts are to be applied the key vehicles driving towards student teacher development process with a primary aim to foster the new generation researcher-teachers who need to develop themselves continuously, to keep pace with new technology and innovative bodies of knowledge, and to be capable of applying the research results to improve their instruction to help develop their students in terms of academic achievements, learning skills and life skills that will enable them to survive, to live with others happily and harmoniously, and finally, to create and sustain a peaceful society.

\section{Conclusion and Recommendations}

From the research results, it can be concluded that the approaches to developing leadership of student teachers who tend to become the real teachers in the not too distant future focus on personal growth and growth as a leader. Overall, both are the critical aspects with the highest means in the desirable state of future teacher leadership development. To effectively develop students' characteristics based on the human value creating global citizenship concept, it requires student teachers' capability and skills, including the roles of school administrators, teacher mentors/supervisors in supporting and guiding student teachers to efficiently manage their instructional activities and to effectively help develop students, endowing them with the desirable characteristics of global citizens who could conduct their lives based on both knowledge and wisdom, and who respect human value in themselves and others. These are, overall, the significant aspects with the highest PNIModified

Recommendations for applying the research results:
1. Universities or higher education institutions, including schools and faculties in

charge of producing teachers and educational personnel and all the parties concerned can apply the research results as the lessons learned and guidelines for conducting future research on the possibility of implementing the proposed approaches to developing future teacher leadership to enhance students' characteristics based on the human value creating global citizenship concept in their units/organizations and in other kinds of educational institutions with the similar context, owing to the research result which reveals that, overall, the desirable state of each aspect falls on the highest level.

2. Administrators and personnel in charge of managing curriculum relating to

producing teachers, including teacher mentors and people concerned can apply the proposed approaches to developing future teacher leadership as a database for improving and upgrading the quality of educational curriculum and programs in order to enhance the personal growth and leadership of student teachers or those who tend to be in the teaching profession, so that they could become a driving force in improving students' desirable characteristics based on the human value creating global citizenship concept, due to the research result which turns out that, overall, these 2 aspects of the desirable state of developing future teacher leadership are at the highest level.

3. Student teachers from any educational institutions could apply the proposed

approaches to developing future teacher leadership as the guidelines for developing their personal growth continuously to become teacher leaders who effectively help enhance students' characteristics of human value creating global citizens and who efficiently respond to a variety of student needs, owing to the research result which reveals that, overall, personal growth becomes the aspect with the highest mean, in terms of the desirable state of developing future teacher leadership.

Recommendations for further studies:

From the above research results and discussions, there are some recommendations for further studies. 
1. A study on a model of developing future teachers of an educational institution, especially in the dimensions of personal growth and leadership, in response to the global contexts and societies in the $21^{\text {st }}$ century should be conducted to help create the new generation teachers and teacher leaders with a growth mindset and a strong determination who can adapt themselves to any changes and develop their professional skills to meet a global standard.

2. There should be a study on the strategies for developing future teachers' competencies to respond to the needs of an educational ecology in the new era, in terms of various aspects, such as a knowledge and wisdom-based leader competency which will help elevate one's honesty and social responsibility, a networking competency, a dialectic critical thinking competency, a creative and innovative thinking competency, a problemsolving competency, transformational management competency, including emotional intelligence, which will significantly help enhance both future teachers' and students' desirable characteristics of respecting human value in themselves and others.

3. An exploration on an innovation for developing future teachers to be equipped with some necessary soft skills required for the pedagogical tasks, as well as some social skills for living together with others in happiness and harmony, should also be carried out to serve as a pathway towards a peaceful society.

\section{References}

[1] Andrea, B. et al. (2016). Knowledge Sharing Problems from the Viewpoint of Intergeneration Management. In ICMLG2016-4th International Conference on Management, Leadership and Gevernance: ICMLG2016. (p.42). Maldives: Academic Conferences and publishing limited.

[2] Bourn, D. \& Sharma, N. (2008). The role of engineers being positive in world change - issues and concerns of engineering graduates in UK. Proceedings of the Institution of Civil Engineers Municipal Engineer,3, 199-206.

[3] Charoenkul, N. et al. (2019). School Management based on the Human Value Creating Global Citizenship Concept. A
Research Report. Bangkok, Thailand: The RU-CU Value Creating Education Research Unit, Chulalongkorn University.

[4] Fairman, J.C., \& Mackenzie, S.V. (2015). How Teacher Leaders Influence Others and Understand their Leadership. In International Journal of Leadership in Education, 18 (1), 61-87.

[5] Fairman, J.C., \& Mackenzie, S.V. (2012). Spheres of Teacher Leadership Action for Learning. In Professional Development in Education: Teacher Leadership and Professional Development, Special Issue, 38, 229-246.

[6] Filipczak, B. et al. (2000). Generations at work: Managing the clash of veterans, boomers, Xers, and nexters in your workplace. New York: AMACOM.

[7] Ikeda, D., in Soka Gakuen Educational Foundation. (2009). Soka Gakuen: A System for Cultivating Human Values. Tokyo: Printer Toppan Printing Co., Ltd.

[8] Kanchanavasee, S. (2009). The Classical Test Theory. Bangkok: The Faculty of Education, Chulalongkorn University. (Available in Thai.)

[9] Krejcie, R.V. \& Morgan, D.W. (1970). Determining Sample Size for Research Activities. In Educational and Psychological Measurement, 30, 607-610.

[10] Mesinsee, S. (2019). New Generation Teachers 4.0. A Declaration of the Policy and Concepts on New Generation Teacher Development, at the Ministry of Higher Education, Science, Research and Innovation, 20 May 2019. (Available in Thai.)

[11] Office of the Education Council. (2017). A System and Model of Teacher Development befitting the Thai and Global Societies. Bangkok, Thailand: Prik Wan Graphics, Co.Ltd., 142-143. (Available in Thai). Office of the Education Council. (2017). National Education Plan (20172036). Bangkok: OEC. Office of the Education Council. (2019). National Education Standards 2018. Bangkok: 21st Century, Co., Ltd. 
[12] Office of the National Economic and Social Development Commission. (2017). The National

[13] Plan for Economic and Social Development 12 (2017-2021). Retrieved on 25 October 2020 from http://www.nesdc.go.th.

[14] Pike, G., \& Selby, D. (2000). In the Global Classroom, Vol. 2. 1st Edition. Ontario, Canada: Pippin Publishing.

[15] Poekert, P.E. et al. (2016). How Teachers Become Leaders: An Internationally Validated Theoretical Model of Teacher Leadership Development. In Research in PostCompulsory Education, 21 (4), 307-329.

[16] Salazar, Y. C. (2010). Teacher to Leader: A mixed methods approach to investigatingteacher leadership in program improvement secondary schools. (Unpublished doctoral dissertation).

Retrieved on 25 October 2020 from: http://sdsudspace

[17] Sharma, N. (2018). Integrating Buddhist: Soka Perspectives within the UNESCOLed Discourse and Practice of Global Citizenship Education. A Public Lecture in DERC Seminar Series for Development Education. Retrieved on 17 April 2020 from

[18]

https://www.youtube.com/watch?v=nDWlFatdGuQ $\& \mathrm{t}=1536 \mathrm{~s}$

[19] Sophonpanich, K.. (2020). Ethics leading Knowledge for Education Management in the Digital Era. The Educational Seminar Project for National Academic Presentation and Educational Management Social Interaction Activity 2020, at Lotus Pang Suan Kaew, Chiang Mai. Bangkok: The Association of Professional Development in Educational Management, Thailand (APDEM). (Available in Thai.)

[20] Srisa-arn, V. (2020). The Leadership Behaviour's Framework by the Institute for Developing

[21] Leadership and Social Innovators, Professor Dr. Vichit Srisa-arn Foundation.
- The Educational Seminar Project for National Academic Presentation and Educational Management Social Interaction Activity 2020, at Lotus Pang Suan Kaew, Chiang Mai. Bangkok: The Association of Professional Development in Educational Management, Thailand (APDEM). (Available in Thai.)

[22] UNESCO. (2014a). Global Citizenship Education Preparing learners for the challenges of the $21 \mathrm{st}$ century. France: UNESCO.

[23] UNESCO. (2014b). Learning to Live Together. Bangkok, Thailand: UNESCO Bangkok Office. 